\title{
Monitoring of Soil Copper Concentrations in Different Organic Farms over a Three-Year Period in Apulia, South-Eastern Italy
}

\author{
Maria Rosaria Provenzano ${ }^{1 *}$, Hamid El Bilali ${ }^{1}$, Vito Simeone ${ }^{2}$, \\ Donato Mondelli ${ }^{1}$, Nuray Baser ${ }^{2}$ \\ ${ }^{1}$ Dipartimento di Biologia e Chimica Agro-Forestale e Ambientale, Università di Bari, \\ Via G. Amendola 165/a, 70126, Bari, Italy \\ ${ }^{2}$ Istituto Agronomico Mediterraneo di Bari, Via Ceglie 9, 70010 Valenzano, Bari, Italy
}

Received: 18 September 2008. Accepted: 14 February 2009.

\begin{abstract}
Copper is considered as a cornerstone of grapevine downy mildew and olive fly management in Apulian organic farms in particular and in the Mediterranean area in general.

In this work we studied the influence of soil properties, cultural practices, and pest management strategies on copper concentrations and accumulation in organic vineyards and olive groves of Apulia (south-eastern Italy).

In 2005, 2006, and 2007 about 70 soil samples were collected from 13 organic olive groves and vineyards at 0-0.2 $\mathrm{m}$ and 0.2-0.4 $\mathrm{m}$ depths in five Apulian organic farms representing a wide range of soils physicochemical properties. Results of physical and chemical analyses, carried out in 2005 and 2007, highlighted notable differences between soil samples in terms of total carbonate, clay, and organic matter contents, while $\mathrm{pH}$ values were very similar. Copper input in 2004, 2005, and 2006 ranged from 7.6 to $46.8 \mathrm{~kg} / \mathrm{ha}$. Total copper concentrations, determined in 2005,2006 , and 2007 with ICP-OES, showed a moderate $\mathrm{Cu}$ accumulation, higher in the shallow layer than in the subsoil and in vineyards than in olive groves in all the sampled farms and for both sampling layers. $\mathrm{Cu}$ accumulation increased with increasing copper-based treatments number and application rates, and also with increasing $\mathrm{pH}_{\mathrm{H} 2 \mathrm{O}}$, clay, and organic matter. Copper availability was higher in the shallow layer than in the subsoil and in vineyards than in olive groves especially in 0-0.2 m layer. Results showed that copper has a medium accumulation in Apulian soils, therefore regulations limiting its use (i.e. CR 473/2002) should be rigorously applied and its alternatives use should be encouraged in order to minimize possible long term effects on soils.
\end{abstract}

Key-words: copper, soil, organic vineyards, organic olive groves.

\section{Introduction}

Italy is one of the leading country in Europe and in the Mediterranean area in terms of organically managed land surface. In 2006, organic agriculture covered 1,067,102 ha of Italy's agricultural land. Organic groves cover 106,936 ha while organic vineyards cover 33,885 ha (Willer and Yussefi, 2007). Apulia represents $9 \%$ of the Italian organic land whereas organic surface represents $6.9 \%$ of the regional agricultural area. Olive groves cover $28 \%$ (23,258 ha) and vineyards cover $3 \%(2,888 \mathrm{ha})$ of the re- gional organic agriculture surface, respectively (Pugliese, 2006).

Copper is one of the most important pesticides used in organic farms. It is effective against a high number of crops pests being utilized as a fungicide, a bactericide and also as a herbicide. More than 300 plants pests can be controlled by copper-based formulations (CDAUK, 2003; Belcari and Bobbio, 1999).

Commission Regulation (CR) N. 473/2002, amending the Council Regulation N. 2092/91 on organic agriculture, limited copper use to 6 $\mathrm{kg} / \mathrm{ha} /$ year from 2006 and further reductions are

* Corresponding Author: Tel.: +39 080 5442929; Fax: +39 080 5442830. E-mail address: provenza@agr.uniba.it 
not excluded in the future. On the opposite of many other pesticides, copper use limitation is not due to its residues in food products or its negative impacts on consumers' health but rather to its accumulation in soils that can lead to a reduction of soil biological activity. In fact, it is neither degraded nor metabolized in the soil where it tends to build up (Besnard et al., 2001; Pietrzak and McPhail, 2004) and can become toxic to soil-dwelling organisms (Banu et al., 2004). Copper is one of the essential elements for all living organisms; however it becomes toxic at concentration exceeding certain limits. Plants requirements in copper are very low and they hardly reach $1-2 \mathrm{~kg} / \mathrm{ha} /$ year (Gessa and Ciavatta, 2005).

Organic matter and $\mathrm{pH}$ are the main factors that influence copper accumulation and availability in soil (Schulte and Kelling, 1999). Copper is soluble in acid environments (Adriano, 1986) and precipitates in alkaline media (Adriano, 1986; ATSDR, 1990).

Average copper concentration in uncontaminated Italian soils is about $50 \mathrm{mg} / \mathrm{kg}$, with values ranging between 5 and $100 \mathrm{mg} / \mathrm{kg}$ (Gessa and Ciavatta, 2005). In Italy, soil copper attention threshold has been fixed at $100 \mathrm{mg} / \mathrm{kg}$ (Decrees 99/92 and 22/97) while allowed maximum copper limit is $120 \mathrm{mg} / \mathrm{kg}$ for soils destined to residential and recreational uses. That limit becomes $600 \mathrm{mg} / \mathrm{kg}$ when soils are dedicated to commercial and industrial uses (Ministerial Decree 471/99).

Although in the Apulian organic farms in particular and in the Mediterranean area in general, copper is considered as a cornerstone of grapevine and olive trees pest management, few information are available on its environmental impact on soils in this area.

The objective of the present research is to monitor copper concentrations in some Apulian organic olive groves and vineyards and to relate them to the main soil physical and chemical characteristics (organic matter, clay, carbonate, and $\mathrm{pH}$ ) and to crops and pests management practices (number of treatments and doses).

\section{Materials and methods}

\section{Soil sampling}

For the purpose of this study, five organic farms operating in the Apulia region (Bari and Taran- to provinces) were selected. During April and May 2005, 2006 and 2007, before organic farmers started treatments during the new olive and vine growing seasons, soil samples were collected at 0-0.2 $\mathrm{m}$ and 0.2-0.4 $\mathrm{m}$ depths in the following organic farms: IAMB, Papparicotta, De Carlo, Pietrarossa and La Pizzica. Selected farms represent a wide range of soils physicochemical properties and microclimates. In each farm and at each site, three sub-samples were collected from different places, which were bulked to obtain a representative sample for the site. At least three samples were taken from each field. Sampling points were referenced in 2005 in order to sample soils from the same points during the following years.

\section{Control selection}

In order to estimate background/baseline total copper concentrations in each farm and sampling site, soil samples were also collected at the same depths from some untreated locations, fallows, and other fields, as close as possible to vines and olive trees lines.

In the case of La Pizzica farm, a cereals (oat) field, on which no copper was used during last years was considered as a control for olive groves and vineyards. In the remaining four farms (IAM-B, Papparicotta, Pietrarossa, and De Carlo), control samples were collected from the fields edges in order to have samples with the same soil characteristics.

Olive groves (extensive or semi-extensive crop) edges are quite large so that control samples can be collected at a long distance (10-20 $\mathrm{m})$ from the fields edges. In vineyards, which are grown in an intensive way in Apulia, control samples were collected at 5-10 m from fields edges. Therefore, in the case of vineyards it is not possible to completely exclude the existence of a drift or shift effect especially when highpressure sprayers (atomizers) are used for performing treatments. Applications were performed by farmers but we asked them to pay attention while treating in order to have accurate results. Therefore, it must be stressed that the selection of a suitable control soil, which is basic in order to make reliable comparisons, must be carried out in the most accurate way when considering field situations like those found in the course of the present work in organic vineyards of Apulia. 


\section{Soil physical and chemical analyses}

Prior to analysis, soil samples were air-dried at greenhouse temperature (approximately 25-30 ${ }^{\circ} \mathrm{C}$ ), lightly ground, mixed thoroughly in order to homogenise them, and sieved through a $2 \mathrm{~mm}$ stainless steel sieve. Soils chemical and physical analyses were carried out in accordance with internationally recommended and accepted analysis procedures and/or Italian official methods (MiPAAF, 1999). Particles sizes distribution was determined using the pipette method (Gee and Bauder, 1986), after dispersion of soil samples with sodium hexametaphosphate and sodium carbonate solutions. Textural classes were determined in accordance with USDA classification. Soil $\mathrm{pH}$ was measured by a glass electrode (Crison Basic 20 $0^{\circledR}$ in distilled water $\left(\mathrm{pH}_{\mathrm{H} 2 \mathrm{O}}\right)$ and in a $1 \mathrm{M} \mathrm{CaCl}_{2}\left(\mathrm{pH}_{\mathrm{CaCl} 2}\right)$ using a suspension 1:2.5 soil to liquid phase ratio. Electrical conductivity (EC) was determined by a conductimeter (XS 510 ${ }^{\circledR}$ on an aqueous extract (soil filtrate) of a mixture soil to water 1:2.5 ratio. Organic carbon was determined by Walkley \& Black method modified by Jackson (1958). Total carbonate was determined using a volumetric method based on its dissolution by hydrochloric acid $(\mathrm{HCl})$ followed by measurement in Dietrich-Fruehling calcimeter. Active calcium was extracted with ammonium oxalate and titrated by potassium permanganate $\left(\mathrm{KMnO}_{4}\right)$. Simultaneous extraction of available $\mathrm{Cu}, \mathrm{Fe}, \mathrm{Zn}$, and Mn was made, only in 2007, by DTPA (0.05 M DTPA, diethylenetriaminepentaacetic acid + $0.01 \mathrm{M} \mathrm{CaCl}_{2}+0.1 \mathrm{M}$ TEA, trietanolamine, solution buffered at $\mathrm{pH}=7.3$ ) and suspensions were shaken for $2 \mathrm{~h}$ at $25^{\circ} \mathrm{C}$ at 80 shakings/min (Lindsay and Norvell, 1978). Suspensions were then filtered through Whatman no. 42 filter paper before their analysis by ICP-OES (Thermo Electron, ICAP 3000) at the following wavelengths: $\mathrm{Cu}$ at $324.75 \mathrm{~nm} ; \mathrm{Zn}$ at $213.85 \mathrm{~nm} ; \mathrm{Mn}$ at $257.61 \mathrm{~nm}$; and $\mathrm{Fe}$ at $239.56 \mathrm{~nm}$.

\section{Copper predicted environmental concentrations (PECs)}

In the Environmental European Agency glossary (2009), PEC is defined as "the estimated concentration of a chemical in an environmental compartment calculated from available information on its properties, its use and discharge patterns, and the quantities involved".
PECs are estimated taking into consideration that copper, as all inorganics, does not degrade between its application and sampling. Moreover, it is assumed that the whole quantity of copper sprayed remains in the top $0.1 \mathrm{~m}$ horizon and that all sampled soils have a bulk density equal to $1.25\left(\mathrm{~g} / \mathrm{cm}^{3}\right)$. It is also assumed that even if plants intercept a part of copper during treatments, that fraction ends up in soils after rain-induced washing-off or after leaves drop. Of course, it is supposed that copper-based pesticides application was homogeneous in all fields. Copper leaching is assumed to be low since there is a short period between copper application and soils sampling and analysis. Furthermore, none of the sampled soils is sandy. In addition, it is also assumed that the amount of copper absorbed by plants and stored in the different organs (leaves, bunches, shoots, etc.) that are removed by some cultural operations (hard and green pruning, bunches thinning, harvest, etc.) is so small that it can be neglected. Calculated PECs represent, somehow, the theoretical annual input of copper in treated soils.

\section{Total copper analysis}

Total copper concentrations were determined in 2005, 2006, and 2007 as follows: $0.5 \mathrm{~g}$ of fine soil were put in $50 \mathrm{ml}$ Teflon vessels, $3.0 \mathrm{ml}$ of $75 \%$ $\mathrm{HNO}^{3}, 1.0 \mathrm{ml} 37 \% \mathrm{HCl}$ and $1.0 \mathrm{ml}$ of $30 \% \mathrm{H}^{2} \mathrm{O}^{2}$ were added. Digestion was carried out in a microwave oven (CEM, MarsX Press) as follows: $3 \mathrm{~min}$ at $140{ }^{\circ} \mathrm{C} ; 3 \mathrm{~min}$ at $165^{\circ} \mathrm{C}$, and $20 \mathrm{~min}$ at $190^{\circ} \mathrm{C}$. Soil extracts were then filtered by Whatman 42 paper filter and analyzed by an optical emission spectrometer (Thermo Electron ICAP $3000)$ at $324.75 \mathrm{~nm}$ wavelength. All chemicals used were of analysis grade and purchased from Aldrich (Sigma-Aldrich, Milan, Italy).

\section{Statistical analyses}

Copper concentrations and soils properties were analysed by one-way analysis of variance (ANOVA) and Student's T-test. Duncan test was used for multiple range comparison of means. Significant differences were determined at $P \leq 0.05$. Linear regressions were used to test relationships between various soil properties with total and available copper concentrations. Correlation analyses were performed using the Least Squares method. An SPSS (Statistical Package for the Social Sciences) software ver- 
sion (SPSS 12.0 for Windows) was used to carry out all above-mentioned statistical tests.

\section{Results and discussion}

\section{Soil physical and chemical properties}

Chemical and physical analyses highlighted notable differences in terms of total carbonate, clay, and organic matter contents even when considering soils sampled from the same farm and at the same depth, while $\mathrm{pH}$ values were very similar (Tab. 1). No significant differences were observed in terms of organic matter (OM) and clay contents between soils sampled in the same farm and field but at different depths. Most soils had silt loamy and loamy textures according to USDA classification. Clay content increased with increasing depth. In 0-0.2 m layer, it ranged from $60 \mathrm{~g} / \mathrm{kg}$ (La Pizzica olive grove) to $304 \mathrm{~g} / \mathrm{kg}$ (La Pizzica vineyard) while in the subsoil $(0.2-0.4 \mathrm{~m})$ it ranged from $75 \mathrm{~g} / \mathrm{kg}$ ( $\mathrm{La}$ Pizzica olive grove) to $371 \mathrm{~g} / \mathrm{kg}$ (De Carlo olive grove). Most $\mathrm{pH}\left(\mathrm{pH}_{\mathrm{H} 2 \mathrm{O}}\right.$ and $\left.\mathrm{pH}_{\mathrm{CaCl} 2}\right)$ values were above 7 . As expected, $\mathrm{pH}_{\mathrm{H} 2 \mathrm{O}}$ was higher than $\mathrm{pH}_{\mathrm{CaCl} 2}$. EC values were similar in both sampling layers. They ranged from $0.11 \mathrm{dS}$ (La Pizzica olive grove) to $0.45 \mathrm{dS}$ (IAM-B vineyard) in the shallow layer while in the subsoil they ranged from $0.13 \mathrm{dS}$ (Pietrarossa olive grove) to $0.36 \mathrm{dS}$ (La Pizzica olive grove). As expected, OM contents were higher in the shallow sampling layer with respect to the subsoil. In $0-0.2 \mathrm{~m}$ layer, values ranged from $6.6 \mathrm{~g} / \mathrm{kg}$ (La Pizzica olive grove) to $55.9 \mathrm{~g} / \mathrm{kg}$ (La Pizzica cherry orchard). In 0.2-0.4 m layer, they ranged from $5.9 \mathrm{~g} / \mathrm{kg}$ (La Pizzica olive grove) to $48.2 \mathrm{~g} / \mathrm{kg}$ (La Pizzica cherry orchard). Total carbonate (TC) showed a high variability from a farm to another. Contents were higher in organic vineyards than in olive groves probably because Apulian vine growers are used to grind calcareous rocks of the primary ecosystem when they establish new vineyards whereas this agronomical practice is not adopted in Apulian olive groves. In $0-0.2 \mathrm{~m}$ layer, TC contents ranged from $8 \mathrm{~g} / \mathrm{kg}$ (Pietrarossa olive grove) to $765 \mathrm{~g} / \mathrm{kg}$ (La Pizzica olive grove) while in the subsoil layer they ranged from $5 \mathrm{~g} / \mathrm{kg}$ (Pietrarossa olive grove) to $823 \mathrm{~g} / \mathrm{kg}$ (La Pizzica olive grove).

\section{Copper use}

The average quantities of copper used per ha in 2004, 2005 and 2006 in the different farms and fields and copper predicted environmental concentrations (PECs) are shown in Table 2.

As stated in the Introduction, former limit of $8 \mathrm{~kg} / \mathrm{ha} /$ year of copper has become 6 $\mathrm{kg} / \mathrm{ha} /$ year starting from January $1^{\text {st }}, 2006(\mathrm{Eu}-$ ropean Commission Regulation N. 473/2002)

Table 1. Soil chemical and physical properties. Averages were calculated considering all the samples collected at the same depth, in the same farm, and for the same crop. Organic matter and total carbonate values are expressed as means \pm standard errors.

\begin{tabular}{|c|c|c|c|c|c|}
\hline Farm & Crop & $\begin{array}{l}\text { Depth } \\
(\mathrm{m})\end{array}$ & $\begin{array}{l}\text { Texture class } \\
\text { (USDA) }\end{array}$ & $\begin{array}{l}\text { Organic matter } \\
(\mathrm{g} / \mathrm{kg})\end{array}$ & $\begin{array}{c}\text { Total carbonate } \\
(\mathrm{g} / \mathrm{kg})\end{array}$ \\
\hline \multirow[t]{4}{*}{ IAM-B } & Olive & $0-0.2$ & Silt loam & $30.5 \pm 0.6$ & $38 \pm 3$ \\
\hline & & $0.2-0.4$ & Silt loam & $23.7 \pm 0.3$ & $39 \pm 6$ \\
\hline & Vine & $0-0.2$ & Loam & $25.8 \pm 0.5$ & $197 \pm 22$ \\
\hline & & $0.2-0.4$ & Loam & $20.7 \pm 0.7$ & $228 \pm 22$ \\
\hline \multirow[t]{4}{*}{ Papparicotta } & Vine & $0-0.2$ & Loam & $17.4 \pm 0.4$ & $262 \pm 37$ \\
\hline & & $0.2-0.4$ & Loam & $21.2 \pm 0.6$ & $261 \pm 37$ \\
\hline & Olive & $0-0.2$ & Silt loam & $26.1 \pm 1.1$ & $142 \pm 12$ \\
\hline & & $0.2-0.4$ & Silt loam & $26.6 \pm 0.5$ & $131 \pm 9$ \\
\hline \multirow[t]{4}{*}{ La Pizzica } & Olive & $0-0.2$ & Loam & $21.1 \pm 2.9$ & $472 \pm 52$ \\
\hline & & $0.2-0.4$ & Loam & $16.2 \pm 3.0$ & $538 \pm 85$ \\
\hline & Vine & $0-0.2$ & Loam & $33.6 \pm 2.5$ & $291 \pm 32$ \\
\hline & & $0.2-0.4$ & Loam & $12.5 \pm 1.4$ & $464 \pm 29$ \\
\hline \multirow[t]{4}{*}{ Pietrarossa } & Vine & $0-0.2$ & Loam & $29.6 \pm 1.2$ & $188 \pm 34$ \\
\hline & & $0.2-0.4$ & Loam & $19.2 \pm 0.8$ & $157 \pm 29$ \\
\hline & Olive & $0-0.2$ & Silt loam & $34.8 \pm 2.3$ & $12 \pm 2$ \\
\hline & & $0.2-0.4$ & Silty clay loam & $24.7 \pm 0.7$ & $7 \pm 1$ \\
\hline \multirow[t]{2}{*}{ De Carlo } & Olive & $0-0.2$ & Silt loam & $40.1 \pm 3.3$ & $40 \pm 16$ \\
\hline & & $0.2-0.4$ & Silt loam & $26.1 \pm 1.6$ & $31 \pm 10$ \\
\hline
\end{tabular}


Table 2. Medium-term (2004-2006) copper uses and predicted copper accumulations. "Pappa" stands for Papparicotta and

"Pietra" for Pietrarossa. Med-term copper use represents the sum of copper quantities that were used in 2004, 2005 and 2006. Med-term PEC represent the sum of annual PECs calculated between 2004 and 2006.

\begin{tabular}{|c|c|c|c|c|c|c|c|c|c|}
\hline \multirow[t]{2}{*}{ Farm } & \multirow[t]{2}{*}{ Crop } & \multirow[t]{2}{*}{ Establishment } & \multirow[t]{2}{*}{ Conversion } & \multirow[t]{2}{*}{$\begin{array}{l}\text { First use } \\
\text { of copper }\end{array}$} & \multicolumn{3}{|c|}{$\begin{array}{c}\text { PEC } \\
(\mathrm{mg} / \mathrm{kg})\end{array}$} & \multirow{2}{*}{$\begin{array}{c}\text { Med-term Cu } \\
\text { use (2004-2006) } \\
\text { kg/ha }\end{array}$} & \multirow{2}{*}{$\begin{array}{c}\text { Med-term PEC } \\
(2004-2006) \\
\mathrm{mg} / \mathrm{kg}\end{array}$} \\
\hline & & & & & 2004 & 2005 & 2006 & & \\
\hline \multirow[t]{2}{*}{ IAM-B } & Vine & 2003 & 2003 & 2004 & 4.0 & 10.4 & 5.9 & 25.4 & 20.3 \\
\hline & Olive & 1965 & 2001 & 2004 & 3.2 & 3.2 & 8.0 & 18.0 & 14.4 \\
\hline \multirow[t]{2}{*}{ Pappa } & Vine & 1983 & 1998 & 1996 & 2.0 & 2.2 & 6.4 & 13.2 & 10.6 \\
\hline & Olive & 1972 & 1998 & - & 1.6 & 1.6 & 2.8 & 7.6 & 6.8 \\
\hline De Carlo & Olive & 1994 & 1996 & $1998 / 99$ & 5.6 & 2.4 & 2.4 & 13.0 & 10.4 \\
\hline \multirow[t]{2}{*}{ Pietra } & Vine & 1999 & 1999 & 2000 & 19.2 & 9.6 & 8.6 & 46.8 & 37.4 \\
\hline & Olive & $1940-45$ & 1996 & 1945 & 3.2 & 4.8 & 4.8 & 16.0 & 12.8 \\
\hline \multirow[t]{2}{*}{ La Pizzica } & Olive & 1982 & 1995 & 1996 & 5.7 & 4.8 & 3.1 & 17.1 & 13.4 \\
\hline & Vine & 1990 & 1995 & 1996 & 3.6 & 7.2 & 2.6 & 16.7 & 13.4 \\
\hline
\end{tabular}

and it is calculated considering the whole organic farm surface, considering farm documentation and copper purchase, and not each hectare of that farm or each field. This means, in practical terms and for organic certification purposes, that even when the total quantity of copper used on a specific crop (e.g., grapevine) is higher than $6 \mathrm{~kg} / \mathrm{ha} / \mathrm{year}$, organic farmers can stay in line with the organic regulation limiting the use of copper on another crop (e.g., olive). This practice may solve the problem from the legislative point of view but, for sure, not from the environmental point of view being potentially related to the accumulation of this heavy metal in organic farms. Furthermore, it should be underlined that even when using the same commercial product and making the same number of treatments, the quantity of copper used can be different because it depends also on the use rates and on the quantity of mixture (pesticide + water) that is distributed in each application.

As can be seen in Table 2, large differences are evident in terms of copper quantities used on olive trees and grapevines. These quantities are representative of the annual average amount of copper used in these farms since their conversion to organic agriculture.

Total copper accumulation in soils depends both on the quantity used during the growing season preceding sampling and analysis dates and on the whole copper input (treatments, fertilizers, organic amendments, olive milling waste water, etc.) during previous years especially from farms conversion to organic agriculture. Therefore, farms establishment and conversion years and some data regarding copper historical use are presented also in Table 2.

The highest quantity of copper was used in Pietrarossa vineyard $(46.8 \mathrm{~kg} / \mathrm{ha})$, which should have determined an increase of total copper concentrations in the first $0.1 \mathrm{~m}$ equal to 37.4 $\mathrm{mg} / \mathrm{kg}$. The lowest quantity during the same period was used in Papparicotta olive grove (7.6 $\mathrm{kg} / \mathrm{ha}$ ) with an estimated PEC equal to 6.8 $\mathrm{mg} / \mathrm{kg}$.

\section{Total Copper}

Total copper concentrations were determined in 2005, 2006 and 2007. The influence of depth, crops, copper-based treatments, and soil chemical and physical properties on total copper concentrations was also studied.

In 2005, the highest total copper concentrations were registered in soils where copper was heavily used in treatments. It ranged from 27.2 (La Pizzica olive grove) to $160.7 \mathrm{mg} / \mathrm{kg}$ (Pietrarossa vineyard) in 0-20 layer and from 45.9 (IAM-B olive grove) to $119.8 \mathrm{mg} / \mathrm{kg}$ in 0.2 $0.4 \mathrm{~m}$ (Pietrarossa vineyard). Copper contents exceeded $100 \mathrm{mg} / \mathrm{kg}$ in six samples out of the sampled soils. Copper resulted slightly more concentrated in the deep sampling layer $(66.5 \pm$ $4.3 \mathrm{a}$ in $0-0.2 \mathrm{~m}$ and $71.2 \pm 4.9 \mathrm{a}$ in $0.2-0.4 \mathrm{~m})$. This result contradicts that found by Pietrzak and McPhail (2004) in vineyards soils of Victoria (Australia) where copper resulted more concentrated in shallow layers. This difference may be explained considering that repeated soil cultivations and tillage, to which olive groves and vineyards soils are subjected in Apulia region, result in mixing up the different soil profile lay- 
ers leading to a homogenisation of the metal along the soil profile. However, results obtained in untilled controls were in line with those obtained by Pietrzak and McPhail (2004). Copper was more concentrated in vineyards where high quantities are used for downy mildew management and in treated soils with respect to untreated controls.

In 2006, copper concentrations resulted highly variable in both sampling depths but they were more variable in $0-0.2 \mathrm{~m}$ than in $0.2-0.4 \mathrm{~m}$ one. Similar results were obtained by Brun et al. (1998) in French Mediterranean vineyards. In 0-0.2 m layer, total $\mathrm{Cu}$ ranged from 22.8 ( $\mathrm{La}$ Pizzica olive grove) to $189.9 \mathrm{mg} / \mathrm{kg}$ (Pietrarossa vineyard) while in the subsoil it ranged from 46.9 (Papparicotta vineyard) to $159.6 \mathrm{mg} / \mathrm{kg}$ (Pietrarossa vineyard). These values are lower than those found in northern Italy where climatic conditions are more favourable to grapevine downy mildew. In a study carried out in Italy by Deluisa et al. (1996), average Cu contents of vineyard soils were $297 \mathrm{mg} / \mathrm{kg}$ in the wet Northern mountainous regions where fungicidal treatments against downy mildew are frequent, $200 \mathrm{mg} / \mathrm{kg}$ on the wet plains and only 75 $\mathrm{mg} / \mathrm{kg}$ in the southern dry areas where fungicidal treatments, especially those for controlling downy mildew, are much less frequent.

In 2007, total copper ranged from 24.6 ( $\mathrm{La}$ Pizzica olive grove) to $162.8 \mathrm{mg} / \mathrm{kg}$ (Pietrarossa vineyard). Values were higher in the shallow layer than in the subsoil $(78.8 \pm 4.9 \mathrm{a}$ in $0-0.2 \mathrm{~m}$ and $73.2 \pm 4.8$ a in $0.2-0.4 \mathrm{~m}, \mathrm{P}=0.421$ ). Rusjan et al. (2007) found that soil total copper contents decreased in deeper profile layers in vineyards located in sub-Mediterranean plains of Slovenia. Brun et al. (1998) and Besnard et al. (2001), when studying $\mathrm{Cu}$ distribution with depth, found that input from treatments was essentially concentrated in the upper layers in French vineyards located in the Mediterranean and Champagne regions.

In our study, vineyards contained more total copper than olive groves. An increase of copper concentrations was observed in treated parts with respect to controls except in Papparicotta vineyard. In the 0-0.2 m layer of IAM-B organic vineyard, copper resulted homogeneously distributed when comparing the inter-rows (62.1 $\mathrm{mg} / \mathrm{kg}$ ) and on the rows $(57.8 \mathrm{mg} / \mathrm{kg})$. This result can be considered as an example of the sit- uation likely to be encountered in Apulian vineyards which, as it has been pointed out before, are grown in an intensive way so that the existence of a drift effect cannot be excluded especially when using high-pressure atomizers in a Tendone training system.

Anyway, no significant differences were highlighted between total copper concentrations on the row and between rows $(\mathrm{P}=0.393$ for 0 20 and 0.627 for $20-40$ sampling layers). These results are in disagreement with those found by Pietrzak and McPhail (2004) in Victoria who reported a systematic decrease of total copper concentrations when moving away from vines rows with some differences between young and old vineyards.

Total copper concentrations were comparable, but more variable, to those found by Rusjan et al. (2007) in the Sub-Mediterranean vineyards in Slovenia (71 to $160 \mathrm{mg} / \mathrm{kg}$ ). Brun et al. (1998) found that copper contents ranged from 31 to 251 in French Mediterranean vineyards. Much higher concentrations, up to $1500 \mathrm{mg} / \mathrm{kg}$, were found in some non-coastal European winegrowing regions (Flores-Veles et al., 1996; Brun et al., 1998; Pietrzak and McPhail, 2004). Our values were much lower than those determined in some renewed French winegrowing regions where copper have been used for more than a century, such as Bordeaux $(800 \mathrm{mg} / \mathrm{kg})$, Burgundy and Champagne (400-500 mg/kg) (Brun et al., 1998). The lower values obtained in our work are likely related to the dry climatic conditions occurring in the Mediterranean area which are less favourable to vine downy mildew development thus allowing lower copper applications and also the use of alternative $\mathrm{Cu}$-free active ingredients in Apulian vineyards.

The only significant correlations found between total copper and soil physical and chemical properties were those with available zinc and total carbonate (Tab. 3). Furthermore, copper resulted positively correlated with organic matter contents and $\mathrm{pH}$ values.

\section{Depth influence on total copper accumulation}

An increase of copper contents was observed between 2005 and 2007 especially in the shallow layer. In fact, average copper accumulation was higher in $0-0.2 \mathrm{~m}(10.4 \pm 1.6 \mathrm{mg} / \mathrm{kg})$ than in $0.2-0.4 \mathrm{~m}$ layer $(7.4 \pm 4.2 \mathrm{mg} / \mathrm{kg})$. McLaren 
Table 3. Correlations between total copper concentrations and the main soil properties, 2007. Correlations were calculated considering all the samples taken from the five sampled organic farms in both depths $(0-0.4 \mathrm{~m})$ or making distinction between those collected from the shallow layer $(0-0.2 \mathrm{~m})$ and those that were sampled from the subsoil $(0.2-0.4 \mathrm{~m})$. $\mathrm{R}^{2}$ : Coefficient of determination.

\begin{tabular}{lcccccr}
\hline \multirow{2}{*}{$\begin{array}{l}\text { Vampling depth } \\
\text { Variable }\end{array}$} & \multicolumn{2}{c}{$0-0.4 \mathrm{~m}$} & \multicolumn{2}{c}{$0-0.2 \mathrm{~m}$} & \multicolumn{2}{c}{$0.2-0.4 \mathrm{~m}$} \\
\cline { 2 - 7 } & $\mathrm{R}^{2}$ & Significance & $\mathrm{R}^{2}$ & Significance & $\mathrm{R}^{2}$ & Significance \\
\hline EC $(\mathrm{dS})$ & 0.017 & 0.250 & 0.028 & 0.299 & 0.002 & 0.768 \\
$\mathrm{pH}(1: 2.5)$ & 0.045 & 0.063 & 0.125 & 0.025 & 0.006 & 0.650 \\
Clay $(\mathrm{g} / \mathrm{kg})$ & 0.008 & 0.426 & 0.093 & 0.055 & 0.000 & 0.946 \\
Organic matter $(\mathrm{g} / \mathrm{kg})$ & 0.081 & 0.011 & 0.056 & 0.140 & 0.102 & 0.051 \\
Total carbonate $(\mathrm{g} / \mathrm{kg})$ & 0.115 & 0.002 & 0.113 & 0.034 & 0.122 & 0.032 \\
\hline
\end{tabular}

and Crawford (1973), Stevenson and Fitch (1981), and Besnard et al. (2001) reported that copper tend to accumulate in the upper soil horizons because organic matter is a major $\mathrm{Cu}$ sorbent. However, no significant difference was highlighted between copper accumulation in both depths $(\mathrm{P}=0.408)$. In the shallow layer, the highest copper accumulation was registered in Pietrarossa vineyard, where the highest quantity of copper was used, while the lowest one was recorded in soil samples collected from La Pizzica oat field, where copper has never been used.

\section{Total copper accumulation in the sampled farms}

Copper accumulation changed sensibly when moving from a farm to another. In the shallow layer $(0-0.2 \mathrm{~m})$ it ranged from $15.0 \mathrm{mg} / \mathrm{kg}$ in Pietrarossa samples to $5.0 \mathrm{mg} / \mathrm{kg}$ in Papparicotta farm. In the subsoil $(0.2-0.4 \mathrm{~m})$, copper accumulation ranged from +13.5 in IAM-B farm to $-4.0 \mathrm{mg} / \mathrm{kg}$ in Pietrarossa farm. Anyway, no statistically significant differences were observed between farms in terms of copper accumulation in the shallow sampling layer $(P=0.297)$ as well as in the subsoil $(\mathrm{P}=0.204)$ (Fig. 1).

\section{Crops influence on total copper accumulation}

Copper accumulation was higher in organic vineyards than in olive groves in all sampled farms and for both sampling layers. It is assumed that differences between species within the same farm are due mainly to different $\mathrm{Cu}$ application rates. The highest difference between vineyards and olive groves was found in IAM-B farm in the shallow layer while the lowest difference was determined in the same farm but in the deeper sampling layer. Anyway, differences in terms of copper accumulation between vineyards and olive groves were not significant from the statistical point of view in all

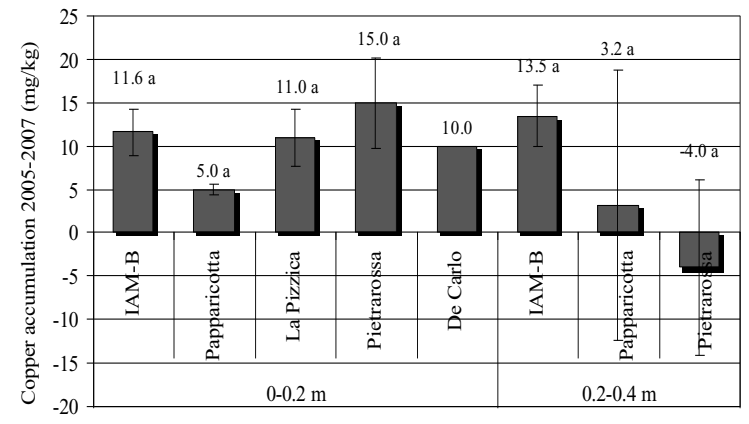

Figure 1. Total copper accumulation in the sampled organic farms between 2005 and 2007. 0-0.2 and 0.2-0.4 m represent sampling depths. Averages were calculated considering only those soils that were sampled trice (2005, 2006 and 2007) at the same depth, and from the same farm. Histograms with different letters are significantly different according to Student's T-test at $\mathrm{P} \leq 5 \%$. Bars represent standard errors of the means.

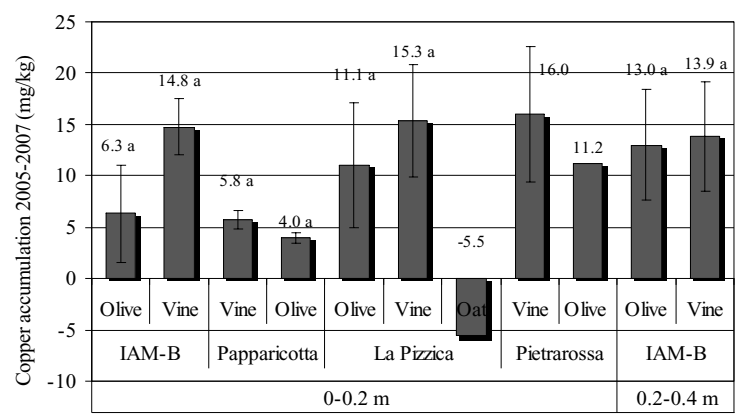

Figure 2. Crops effect on total copper accumulation between 2005 and 2007. 0-0.2 and 0.2-0.4 m represent sampling depths. Values were calculated considering only those soils that were sampled trice $(2005,2006$ and 2007) at the same depth, from the same farm and same field (same crop). Histograms with different letters are significantly different according to Student's T-test at considering first risk value $\mathrm{P} \leq 5 \%$. Letters refer to differences between plant species within the same farm. In the case of La Pizzica farm, statistical analysis regarded only total copper accumulation in the vineyard and the olive grove without taking into consideration samples collected from cereals (oat) field. Bars represent standard errors of the means. 
Figure 3. Comparison of predicted copper accumulation in 2005 and 2006 and its effective accumulation between 2005 and 2007. Values regarding effective copper accumulation represent total copper concentrations increase in the shallow layer between 2005 and 2007. Figures regarding predicted copper accumulations represent its predicted environmental concentrations based on copper use in the different sampled vineyards and olive groves of Apulia in 2005 and 2006.

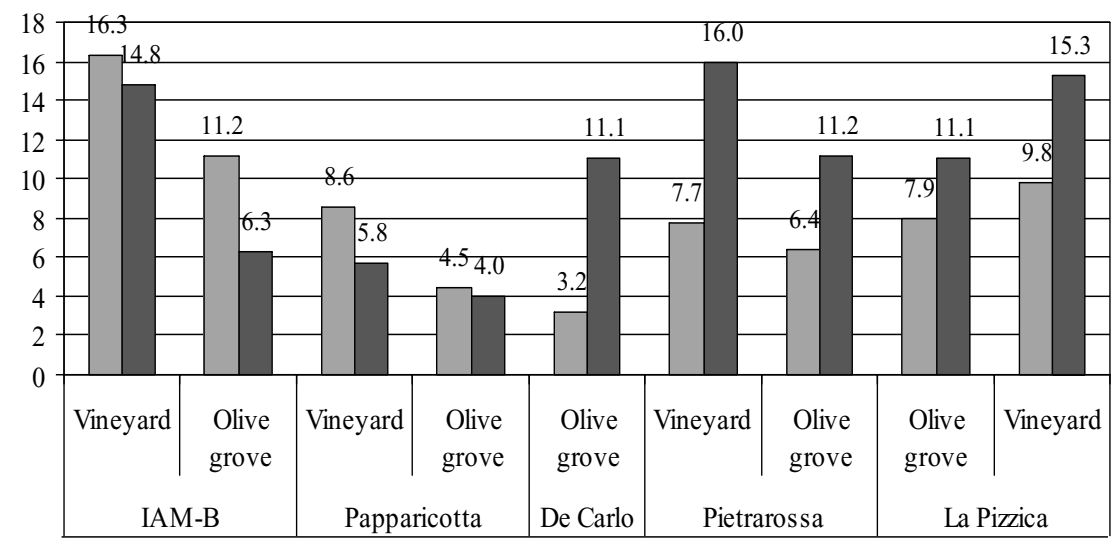

$\square$ Predicted copper accumulation 2005/06 (mg/kg) $\square$ Effective copper accumulation 2005/07 (mg/kg) farms in the shallow layer ( $\mathrm{P}=0.143$ IAM-B; 0.177 for Papparicotta and 0.620 for La Pizzica) as well as in the subsoil ( $\mathrm{P}=0.917$ for IAM-B farm) (Fig. 2).

\section{Effect of treatments on copper accumulation}

In order to investigate the effect of treatments on copper accumulation, we compared predicted copper accumulation based on copper use and its effective concentrations. Copper predicted or estimated accumulation was lower than its effective or observed accumulation except in IAM-B and Papparicotta olive groves and vineyards (Fig. 3). This may be explained also, at least to a certain extent, by copper leaching, uptake by vines and olive trees or other weeds and/or retention at the roots zone. That's why also rainfall should be measured given its effect on copper leaching and runoff. However, runoff phenomena should be very low since this work was carried out in Apulian plains where fields were flat and soil erosion was well controlled also using cover crops.
A positive but not significant correlation between effective or observed copper accumulation (ECA) and predicted copper accumulation (PCA) was observed. In fact: ECA = 1.122 PCA, $\mathrm{R}^{2}=0.399$.

Influence of soil chemical and physical properties on copper accumulation

Copper accumulation increased with increasing $\mathrm{pH}$, clay, and organic matter contents and decreasing total carbonate contents. The highest correlation coefficient and the lowest P-value (significance) were found between copper accumulations and clay contents (Tab. 4).

\section{Available copper}

All soil samples exceeded the threshold of 0.1 $\mathrm{mg} / \mathrm{kg} \mathrm{Cu}$-DTPA (Sims and Johnson, 1991) considered as an indicator of copper deficiency, and most of them reached and went above the upper limit of $2.5 \mathrm{mg} / \mathrm{kg}$. Available copper ranged from 1.0 to $46.4 \mathrm{mg} / \mathrm{kg}$ in $0-0.2 \mathrm{~m}$ layer and from 0.3 to $16.9 \mathrm{mg} / \mathrm{kg}$ in $0.2-0.4 \mathrm{~m}$ one. Copper availability was also significantly influenced by depth

Table 4. Correlations between total copper accumulations and the main soil properties Correlations were calculated considering all the samples collected from the five sampled organic farms. R2: Coefficient of determination. "SE" stands for standard errors.

\begin{tabular}{lccc}
\hline Variable & $\mathrm{R}^{2}$ & $\mathrm{SE}$ & Significance \\
\hline Available $\mathrm{Zn}(\mathrm{mg} / \mathrm{kg})$ & 0.066 & 10.498 & 0.097 \\
$\mathrm{EC}$ & 0.027 & 10.715 & 0.295 \\
$\mathrm{pH}$ & 0.002 & 10.851 & 0.781 \\
$\mathrm{Clay}(\mathrm{C})(\mathrm{g} / \mathrm{kg})$ & 0.087 & 10.327 & 0.058 \\
$\mathrm{OM}(\mathrm{g} / \mathrm{kg})$ & 0.042 & 10.632 & 0.189 \\
$\mathrm{pH}$ & 10.852 & 0.799 \\
Total carbonate $(\mathrm{TC})(\mathrm{g} / \mathrm{kg})$ & 0.002 & 10.558 & 0.130 \\
\hline
\end{tabular}




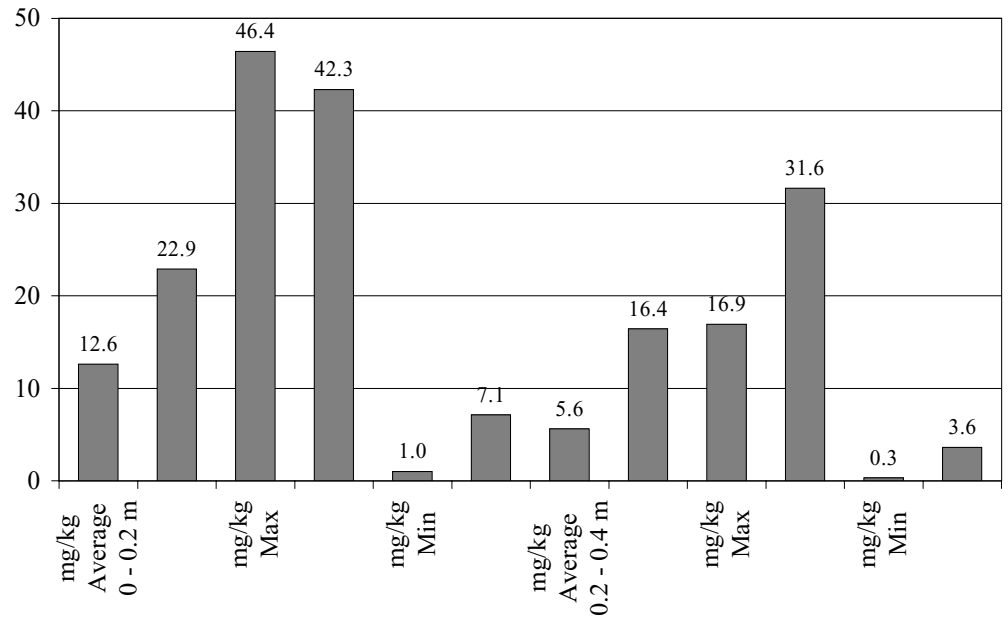

Figure 4. Average, maximum, and minimum available copper concentrations and copper availability. 0-0.2 and $0.2-0.4 \mathrm{~m}$ represent sampling depths. Values were calculated considering all the samples collected from the five sampled farms at the same depth. Histograms with different letters are significantly different according to Student's T-test at $\mathrm{P} \leq$ $5 \%$. Bars represent standard errors of the means.
(22.9\% in $0-0.2 \mathrm{~m}$ and $16.4 \%$ in $0.2-0.4 \mathrm{~m}$ ). Percentages refer to the available heavy metal fraction compared with the total amount. Copper resulted significantly more available and variable in $0-0.2 \mathrm{~m}$ layer ( 7.7 to $42.3 \%$ ) than in the deep one (3.6 to 31.6\%) (Fig. 4). In French Mediterranean vineyards, DTPA-extractable $\mathrm{Cu}$ ranged from 5 to $52 \%$ of total copper (Brun et al., 1998).

Copper availability was high despite the fact that the sampled soils had $\mathrm{pH}_{\mathrm{H} 2 \mathrm{O}}$ values over 7.5. This result is in disagreement with that found by Miller and Donahue (1990) who reported that with basic $\mathrm{pH}$ (aqueous extract) of over 7.5 copper is not readily extracted and is probably immobilised in the topsoil layer. Furthermore, Herms and Brümmer (1984) reported that $\mathrm{Cu}$ solubility in soils is at a minimum between $\mathrm{pH} 5$ and 6 .

ANOVA test showed that "farm" factor had a significant influence on available copper concentrations in both sampling layers. A strong relationship was evident between available copper concentration (expressed as $\mathrm{mg} / \mathrm{kg}$ ) and copper availability (expressed as percentage of available copper on total copper concentrations) since Pietrarossa farm contained the highest available copper concentration and it was also the farm where copper was the most available while La Pizzica farm is characterized by the lowest available copper concentrations and copper availability.

Available copper concentrations resulted higher in organic vineyards with respect to olive groves except in IAM-B farm. In both sampling depths (0-0.2 and 0.2-0.4 m), available copper concentrations and copper availability were higher in treated fields parts with respect to untreated ones both in organic vineyards and in olive groves.

\section{Conclusions}

During the period 2005-2007, total and available copper concentrations were determined on about 70 soil samples collected at $0-0.2 \mathrm{~m}$ and 0.2-0.4 m depths from 13 organic olive groves and vineyards in five Apulian organic farms.

In the case of vineyards, grown in an intensive way, the importance of a suitable selection of control soils was stressed, since the existence of drift and shift effects cannot be excluded, especially when high-pressure sprayers (atomizers) are used for performing treatments.

In the sampled farms, copper application in 2004, 2005, and 2006 ranged from 7.6 to 46.8 $\mathrm{kg} / \mathrm{ha}$, whereas average total copper accumulation ranged from +15.0 to $+5.0 \mathrm{mg} / \mathrm{kg}$ in $0-0.2$ $\mathrm{m}$ layer and from +13.5 to $-4.0 \mathrm{mg} / \mathrm{kg}$ in the $0.2-$ $0.4 \mathrm{~m}$ depth. Total copper concentrations were much lower than those determined in some noncoastal European area and in some famous French winegrowing regions. This result were ascribed to the dry climatic conditions occurring in the Mediterranean area which are less favourable to vine downy mildew development. They were higher in vineyards than in olive groves in all sampled farms and for both sampling layers and in all soils they increased with 
increasing $\mathrm{pH}_{\mathrm{H} 2 \mathrm{O}}$, clay, and organic matter. Total copper values increased also with increasing copper-based treatments number and application rates.

Regarding copper availability, it was higher in vineyards than in olive groves especially in 0$0.2 \mathrm{~m}$ layer and it was positively correlated with the number of years during which cupric formulations have been used. Copper availability decreased with increasing $\mathrm{pH}_{\mathrm{H} 2 \mathrm{O}}$, clay, and organic matter but it was high despite alkaline $\mathrm{pH}_{\mathrm{H} 2 \mathrm{O}}$ values.

Our results pointed to a moderate copper accumulation in Apulian soils. Nonetheless, alternative non-cupric products should be encouraged in order to minimize the possible long term effects on soils.

\section{Acknowledgements}

Funding for this work was provided by the University of Bari and the Mediterranean Agronomic Institute of Bari (IAM-B) under the Community Initiative Interreg III A Italy-Albania 2000-2006: "Integrated project for the diffusion and technical assistance in the implementation of methodologies for the production of organic products", Acronym: PAB.

\section{References}

Adriano, D.C. 1986. Trace elements in the terrestrial environment. Springer-Verlag, New York, USA, 533 p.

ATSDR 1990. Toxicological profiles for copper. The Agency for Toxic Substances and Disease Registry (ATSDR), Atlanta, Georgia, USA. <www.atsdr.cdc. gov/toxpro2.html> (May 10, 2005).

Banu N.A., Singh B., Copeland L. 2004. Influence of copper on soil microbial biomass and biodiversity in some NSW soils. SuperSoil 2004: $3^{\text {rd }}$ Australian New Zealand Soils Conference, 5-9 December 2004, University of Sydney. Published on cd-rom. <www.regional.org.au/au/asssi> (March 12, 2005).

Belcari A., Bobbio E. 1999. L'impiego del rame nel controllo della mosca delle olive, Bactrocera oleae. Informatore Fitopatologico, 49, 12:52-55.

Besnard E., Chenu C., Robert M. 2001. Influence of organic amendments on copper distribution among particle-size and density fractions in Champagne vineyard soils. Environ. Pollut., 112, 3:329-337.

Brümmer G.W., Gerth J., Herms U. 1986. Heavy metal species, mobility and availability in soils. Z. Pflanzenernaehr. Bodenkd., 149:382-398.

Brun L.A., Maillet J., Richarte J., Hermann P., Remy J.C. 1998. Relationship between extractable copper, soil properties and copper uptake by wild plants in vineyard soils. Environ. Pollut., 102, 2-3:151-161.

CDA-UK 2003. Uses of Copper Compounds. Copper Development Association, United Kingdom. <http:// www.copper.org/compounds/ukcomp.html> (November 6, 2003).

Deluisa A., Giandon P., Aichner M., Bortolami P., Bruna L., Lupetti A., Nardelli F., Stringari G. 1996. Copper pollution in Italian vineyard soils. Commun. Soil Sci. Plant Anal., 27:1537-1548.

Environmental European Agency 2009. Glossary. <http:// glossary.eea.europa.eu/terminology/concept_html?ter $\mathrm{m}=$ pec $>$ (September 10, 2008).

Flores-Veles L.M., Ducaroir J., Jaunet A.M., Robert M. 1996. Study of the distribution of copper in an acid sandy vineyard soil by three different methods. European Journal of Soil Science, 47:523-532.

Gee G.W., Bauder J.W. 1986. Particle size analysis. In: Klute A. (ed.): Methods of Soil Analysis. Part 1. Physical and Mineralogical Methods. Agronomy Monograph N. 9, 383-411. American Society of Agronomy, Soil Science Society of America, Madison, WI, USA.

Gessa C.E., Ciavatta C. 2005. Gli elementi nutritivi Rame. In: Sequi P. (ed.): Fondamenti di chimica del suolo, 399-400. Pàtron Editore, Bologna.

Herms U., Brümmer G.W. 1984. Solubility and retention of heavy metals in soils. Z. Pflanzenernaehr. Bodenkd., 147:400-424.

Jackson M.L. 1958. Soil chemical analysis. Prentice Hall Inc., Englewood Cliffs, New Jersey, USA, 498 p.

Lindsay W.L., Norvell W.A. 1978. Development of a DTPA soil test for zinc, iron, manganese and copper. Soil Sci. Soc. Amer. J., 42:421-428.

McLaren R.G., Crawford D.V. 1973. Studies on soil copper: The fractionation of copper in soils. J. Soil Sci., 24:172-181.

Miller R.W., Donahue R.L. 1990. Soils; An introduction to soils and plant growth. Prentice Hall International, Englewood Cliffs, 767 p.

MiPAAF 1999. Metodi ufficiali di analisi chimica del suolo. Decreto Ministeriale del 13 settembre 1999. Gazzetta Ufficiale della Repubblica Italiana. Supplemento Ordinario N. 284 del 21 ottobre 1999. Ministero delle Politiche Agricole, Alimentari e Forestali (MiPAAF).

Olsen S.R., Sommers L.E. 1982. Phosphorus. In: Page A.L. et al. (eds.): Methods of chemical soil analysis. Part 2. $2^{\text {nd }}$ Ed. Agron. Monogr. 9, 403-430. ASA and SSSA, Madison, WI.

Pietrzak U., McPhail D.C. 2004. Copper accumulation, distribution and fractionation in vineyard soils of Victoria, Australia. Geoderma, 122:151-166.

Pugliese P. 2006. L'agricoltura biologica in Puglia: non solo cifre... <http://www.premiobiol.it/documenti/2006 _ita_AB\%20in\%20Puglia.pdf?PHPSESSID=918b0a4 0b0d3c209b622c5c87ff8e817> (February 14, 2008).

Rusjan D., Strlič M., Pucko D., Korošec-Koruza Z. 2007. 
Copper accumulation regarding the soil characteristics in Sub-Mediterranean vineyards of Slovenia. Geoderma, 141, 1-2: 111-118.

Schulte E.E., Kelling K.A. 1999. Soil and applied copper. Understanding plant nutrients; A2527. University of Wisconsin-Madison and University of Wisconsin-Extension, Cooperative extension. <http://cecommerce.uwex.edu/pdfs/A2527.PDF $>$ (February 16, 2005).

Sims J.T., Johnson G.V. 1991. Micronutrient Soil Tests. In: Mortvedt J.J., Giordano P.M., Lindsay W.E. (eds.):
Micronutrients in Agriculture. $2^{\text {nd }}$ Ed. Soil Science Society of America (SSSA), Madison, 442 p.

Stevenson F.J., Fitch A. 1981. Reactions with organic matter. In: Loneragan J.F., Robson A.D., Graham R.D. (eds.): Copper in Soils and Plants. Golden Jubilee International Symposium on Copper in Soils and Plants, Perth, Western Australia, Academic Press, Sydney, 69-95.

Willer H., Yussefi M. 2007. The world of organic agriculture: statistics and emerging trends. IFOAM and FIBL, Bonn and Frick, 251 p. 